JURNAL ILMIAH KOMPUTER GRAFIS, Vol.14, No.2, Desember 2021, pp. 271 - 286

p-ISSN : 1979-0414 (print)

e-ISSN : 2621-6256 (online)

http://journal.stekom.ac.id/index.php/pixel

page 271

\title{
RANCANGAN SISTEM ADMINISTRASI KEUANGAN RT O04 RW 013 DESA WARINGIN JAYA BOJONGGEDE
}

\author{
Ahmad Husain ${ }^{1}$, Danar Eko Novianto ${ }^{2}$, Caka Gatot Priambodo ${ }^{3}$, Nani Muliyani ${ }^{4}$ \\ Informatika, Universitas Indraprasta PGRI \\ hnr.husen@gmail.com ${ }^{1}$
}

\section{ARTICLE INFO}

Article history:

Received November 2021

Received in revised form 2 Des 2021

Accepted 15 Des 2021

Available online Des 2021

\begin{abstract}
The research objective was to find out what kind of system used in processing the existing finance on Rt.04 RW. 13 Desa Waringin Jaya and the obstacles faced in implementing the application. In addition, the authors hope that readers can understand the use of an application, especially the financial administration system. The research method used by researchers is the Extreme Programming (XP) method, which is a method that includes several rules in practice, consisting of planning, design, implementation / coding and test. During the study the authors found that at Rt. $04 R w .13$ Desa Waringin Jaya does not yet have an effective and efficient financial administration system. After conducting the research, the authors gave conclusions, especially Rt. $04 R w .13$ Desa Waringin Jaya requires a computerized system that is effective and efficient so that it can help the treasurer work. The author makes a system, namely the Financial Administration Application Rt. 04 $R$ W. 13 Waringin Jaya Village based on Java SE.
\end{abstract}

Keywords: System, Application, Financial

JURNAL ILMIAH KOMPUTER GRAFIS Vol. 14, No. 2, Des 2021: $271-286$ 


\section{Pendahuluan}

Pesatnya perkembangan teknologi informasi sangat berdampak pada pemanfaatan teknologi informasi yang sangat besar pada suatu organisasi seperti perusahaan, instansi-instansi, ataupun bidang lainnya. Diharapkan dengan pemanfaatan teknologi informasi mampu meningkatkan kinerja perusahaan atau yang lainnya. Tujuan Penelitian ini untuk merancang sistem administrasi yang efisien dan dapat membantu kinerja Bendahara RT 04 RW 13, menciptakan penyimpanan data keuangan yang efisien, dan dengan adanya aplikasi ini diharapkan bendahara RT dapat dengan mudah mengelola keuangan. Manfaat Mengefisiensikan waktu pekerjaan bagi bendahara RT 04 agar cepat, tepat, dan akurat, serta mengurangi faktor kesalahan manusia (human error).

Perancangan adalah proses merencanakan segala sesuatu terlebih dahulu. Perancangan merupakan wujud visual yang dihasilkan dari bentuk-bentuk kreatif yang telah direncanakan. Langkah awal dalam perancangan desain bermula dari hal-hal yang tidak teratur berupa gagasan atau ide-ide kemudian melalui proses penggarapan dan pengelolaan akan menghasilkan hal-hal yang teratur, sehingga hal-hal yang sudah teratur bisa memenuhi fungsi dan kegunaan secara baik. Perancangan merupakan penggambaran, perencanaan, pembuatan sketsa dari beberapa elemen yang terpisah kedalam satu kesatuan yang utuh dan berfungsi [1]. Perancangan sistem adalah suatu fase dimana diperlukan suatu keahlian perancangan untuk elemen-elemen komputer yang akan menggunakan sistem, yaitu pemilihan peralatan dan program komputer untuk sistem yang baru [2].

Aplikasi adalah koleksi window dan objek-objek yang menyediakan fungsi untuk aktivitas user, seperti pemasukan data, proses, dan pelaporan [3]. Laporan keuangan dapat diibaratkan sebuah peta yang berguna bagi pihak-pihak yang sedang melakukan perjalanan [4]. Java menurut definisi dari Sun Microsystem adalah nama untuk sekumpulan teknologi untuk membuat 12 dan menjalankan perangkat lunak pada komputer standalone ataupun pada lingkungan jaringan [5].

\section{Metode Penelitian}

Penulis dalam penelitian ini menggunakan metode Extreme Programming (XP). Extreme Programming (XP) dipilih karena perangkat lunak yang akan dibuat tidak terlalu kompleks dan tergolong perangkat lunak berskala kecil dan juga membutuhkan waktu pengembangan yang tidak terlalu lama . Model Extreme Programming mencakup beberapa aturan dalam prakteknya, yang terdiri dari planning, design, Implementation / Coding dan Test.

Adapun penjelasan dari tahapan metode pengembangan sistem Extreme Programming adalah

1. Planning / Perencanaan

Pada tahapan ini perencanaan terhadap software yang diinginkan mengacu pada user stories. User stories menggambarkan fitur dan fungsi yang dibutuhkan terhadap software tersebut. Ketika semua user stories telah ditentukan, developer akan menentukan lama pengerjaan untuk tiap-tiap user stories. Perencanaan dapat dilakukan apabila sudah mengetahui batasan masalahnya apa saja dalam sistem administrasi keuangan pada tingkat Rt. 04 Rw. 13 Desa Waringin Jaya Bojonggede. Adapun beberapa fungsi dan kebutuhan dari aplikasi adalah sebagai berikut:

a. Mengidentifikasi Permasalahan

b. Membuat User Stories sebagai inti perencanaan dari XP

c. Menentukan visi perangkat lunak

d. Menentukan tujuan perangkat lunak

e. Menentukan pengguna perangkat lunak

f. Menentukan informasi yang dibutuhkan

g. Mengidentifikasi dan menganalisis kebutuhan aplikasi

JURNAL ILMIAH KOMPUTER GRAFIS Vol. 14, No. 2, Des $2021: 271-286$ 
h. Membuat Diagram Alir Data sebagai gambaran umum

i. Membuat Entity Relationship Diagram sebagai gambaran aktivitas perangkat lunak

2. Design

Proses desain pada XP mengikuti prinsip KIS (Keep It Simple). Desain akan berisikan semua implementasi dari stories tanpa ada pengurangan maupun penambahan. Desain yang memiliki fungsi tambahan tidak disarankan. XP menggunakan CRC (Class-Responsibility Collaborator) cards untuk mengidentifikasi dan mengorganisasikan kelas berorientasi objek yang berkaitan dengan proses pengembangan perangkat lunak. Jika terdapat kesulitan untuk melakukan desain terhadap stories, XP menyarankan untuk membuat prototype dari desain tersebut. Hal ini disebut sebagai spike solution, prototype nantinya akan diimplementasikan dan dievaluasi. XP menyarankan refactoring, sebuah teknik pengembangan yang juga teknik desain.

Perubahan desain dapat terjadi walaupun sudah memasuki tahap coding/implementasi. Hal tersebut dilakukan untuk mendapat desain yang baik dan kode yang bersih. Pada desain, perancangan aplikasi terdiri dari beberapa bagian diantaranya sebagai berikut:

a. Perancangan class yang dibutuhkan dengan CRC

Tujuan tahap ini yaitu mengelompokkan fungsi-fungsi yang ada dalam system dan membaginya kedalam kelas. CRC card juga dibutuhkan sebagai panduan membuat fungsi dalam pengkodean.

b. Perancangan Design GUI

Merancang tampilan secara grafis dengan tujuan untuk memudahkan pengguna dalam menjalankan aplikasi dan dapat dengan mudah memahami informasi yang ditampilkan pada aplikasi tersebut. Dalam tahap ini digunakan prinsip-prinsip dari bidang ilmu Interaksi Manusia dan Komputer seperti pemilihan warna, tata letak, pemilihan jenis huruf, dan lainlain.

c. Perancangan Design Database

Pada perangkat lunak ini diperlukan adanya suatu database dalam server yang digunakan untuk meyimpan data warga, data pembayaran iuran dan pengeluaran iuran.

3. Coding

Pada tahap ini, proses pengembangan tidak langsung melakukan implementasi terhadap desain yang telah dibuat. Pembuatan unit test untuk tiap-tiap stories yang nantinya akan diimplementasikan. Saat unit test selesai dibuat, pengembang lebih baik fokus terhadap apa yang akan diimplementasikan untuk melewati unit test. Tahap ini akan mengacu pada desain sebelumnya. Karena pembuatan unit test dilakukan terlebih dahulu maka implementasi desain sebaiknya dibuat untuk melewati unit test yang dibuat. Dalam hal ini penulis melakukan coding menggunakan bahasa pemrograman java SE melalui Netbeans IDE pada perangkat lunak desktop dan database mysql untuk phpmyadmin.

4. Testing

Tahap ini akan menggunakan unit test yang sebelumnya telah dibuat. Karena pembuatan dari unit test adalah pendekatan utama dari XP. Dalam melakukan pengujian, penulis menggunakan 2 teknik pengujian yaitu pengujian white box dan black box. Pada tahap pengujian white box, penulis melakukan pengujian terhadap alur logika berdasarkan metode yang digunakan. Sedangkan pada tahap pengujian black box, dilakukan pengujian setiap unit test, maksudnya melakukan pengujian integrasi antara input dan hasil output yang sesuai semestinya terjadi.

\section{Hasil Dan Pembahasan}

JURNAL ILMIAH KOMPUTER GRAFIS Vol. 14, No. 2, Des 2021 : $271-286$


Data Flow Diagram adalah representasi grafik yang menggambarkan aliran infromasi dan transformasi yang diaplikasikan sebagai data yang mengalir dari masukan dan keluaran [6].

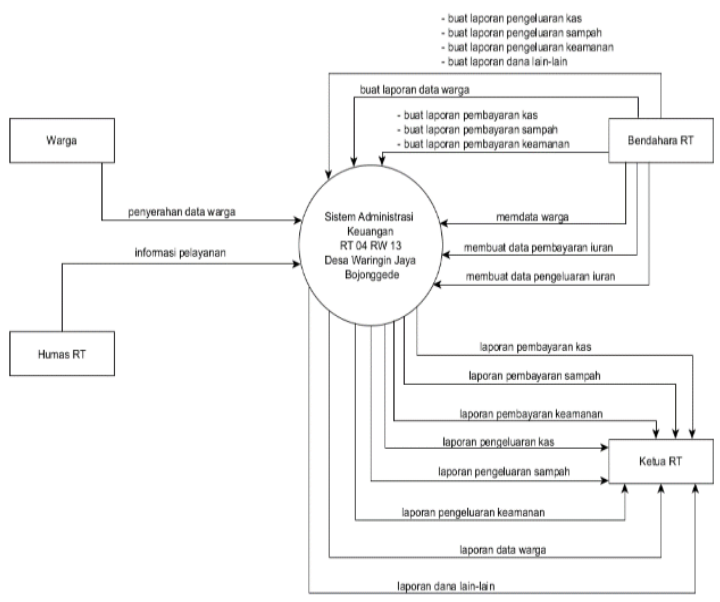

Sumber : Dokumen Pribadi

Gambar 1. Diagram Konteks

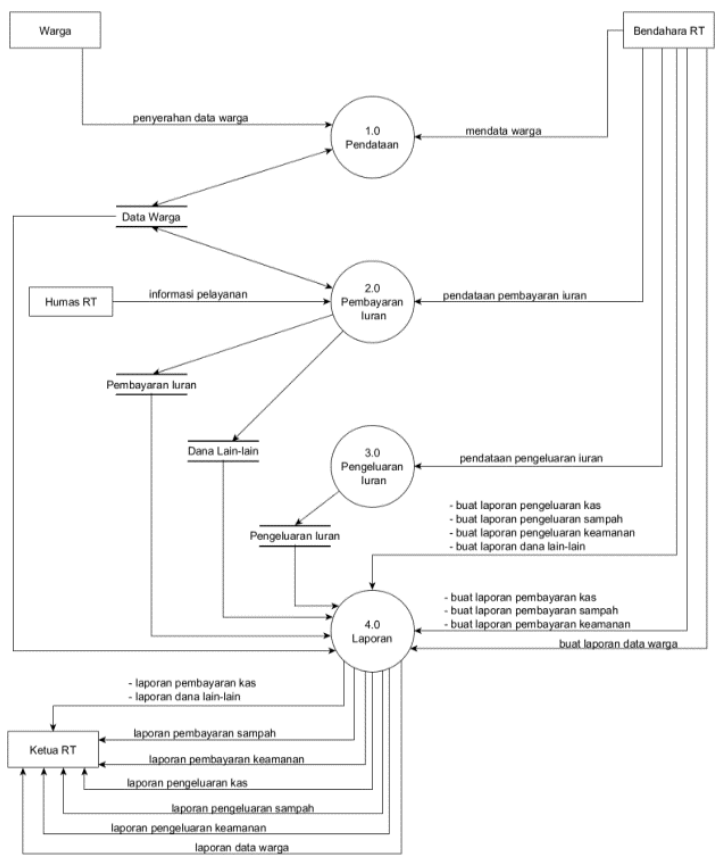

Sumber : Dokumen Pribadi

Gambar 2. Diagram Nol

JURNAL ILMIAH KOMPUTER GRAFIS Vol. 14, No. 2, Des $2021: 271-286$ 
Nomalisasi merupakan sebuah proses pengelompokan data elemen menjadi tabel-tabel yang menunjukan entitas dan relasinya.

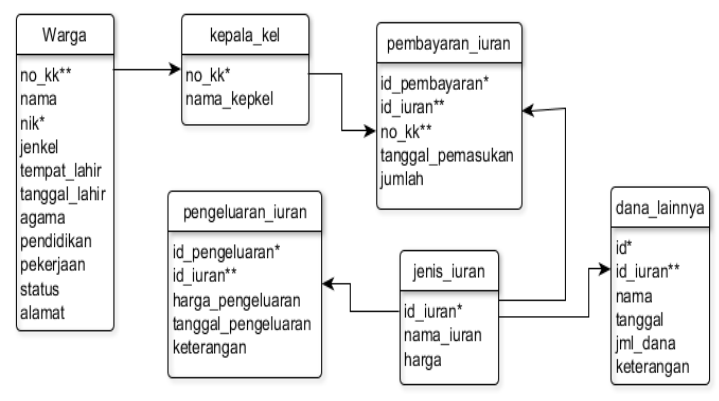

Sumber : Dokumen Pribadi

Gambar 3. Normalisasi

Model Entity Relationship Diagram merupakan jaringan yang menggunakan susunan data yang disimpan secara abstrak, yang bertujuan untuk menunjukan data dan relasi yang ada pada objek tersebut dan merupakan salah satu alat untuk perancangan basis data.

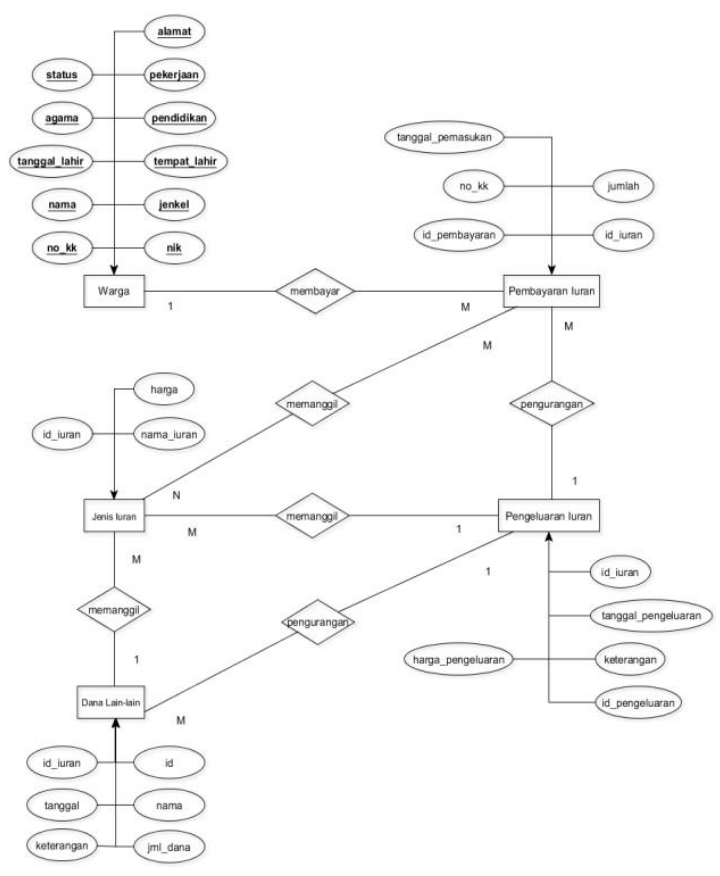

Sumber : Dokumen Pribadi

Gambar 3. ERD

JURNAL ILMIAH KOMPUTER GRAFIS Vol. 14, No. 2, Des 2021: $271-286$ 
Tampilan layar atarmuka pada aplikasi keuangan RT 04 RW 13 seperti di bawah ini:

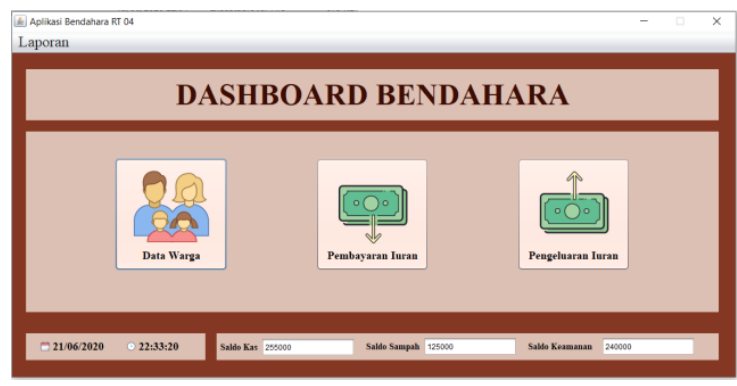

Sumber : Dokumen Pribadi

Gambar 4. Tampilan Menu Utama

Tampilan menu utama berisikan 3 tombol untuk menginput data warga, pembayaran iuran, pengeluaran iuran. Menu bar Laporan untuk mencetak pembayaran iuran, pengeluaran iuran dan data warga.

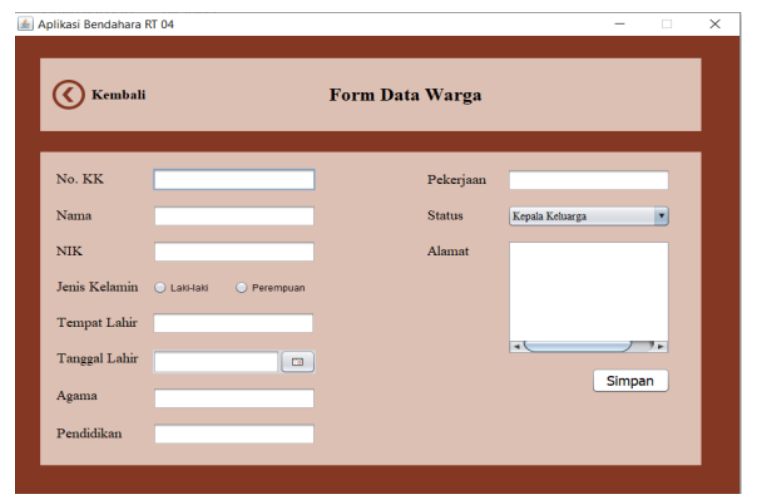

Sumber : Dokumen Pribadi

Gambar 5. Tampilan Form Data Warga

Tampilan form data warga ini berisikan no. kk, nama, nik, jenis kelamin, tempat lahir, tanggal lahir, agama, pendidikan, pekerjaan, status, dan alamat. 


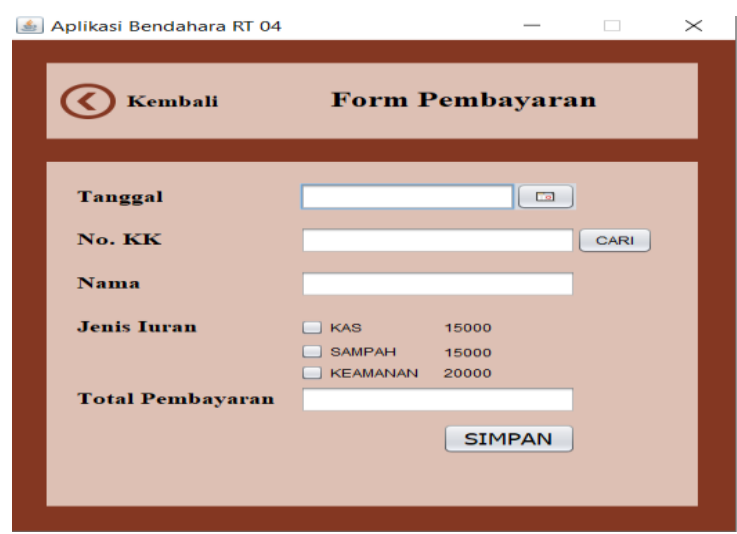

Sumber : Dokumen Pribadi

Gambar 6. Tampilan Form Pembayaran

Tampilan form pembayaran ini berisikan tanggal, no. kk, nama, jenis iuran, dan total pembayaran.

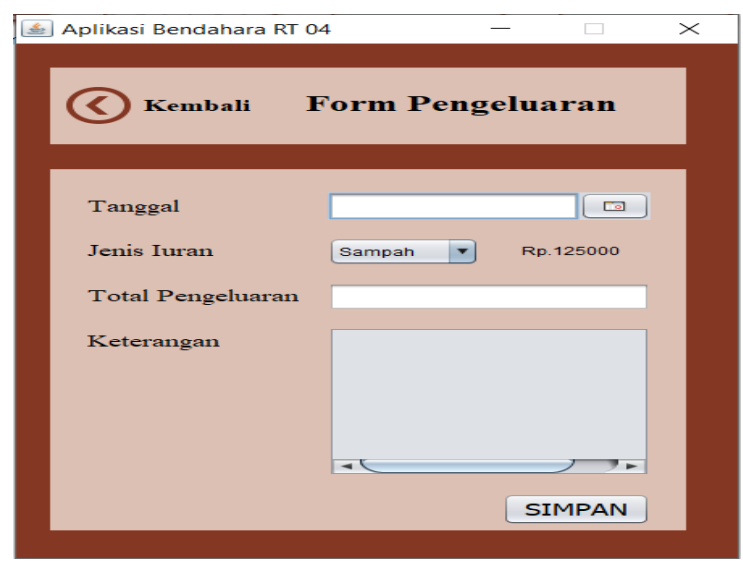

Sumber : Dokumen Pribadi

Gambar 7. Tampilan Form Pengeluaran

Tampilan form pengeluaran ini berisikan tanggal, jenis iuran, total pengeluaran, dan keterangan. 


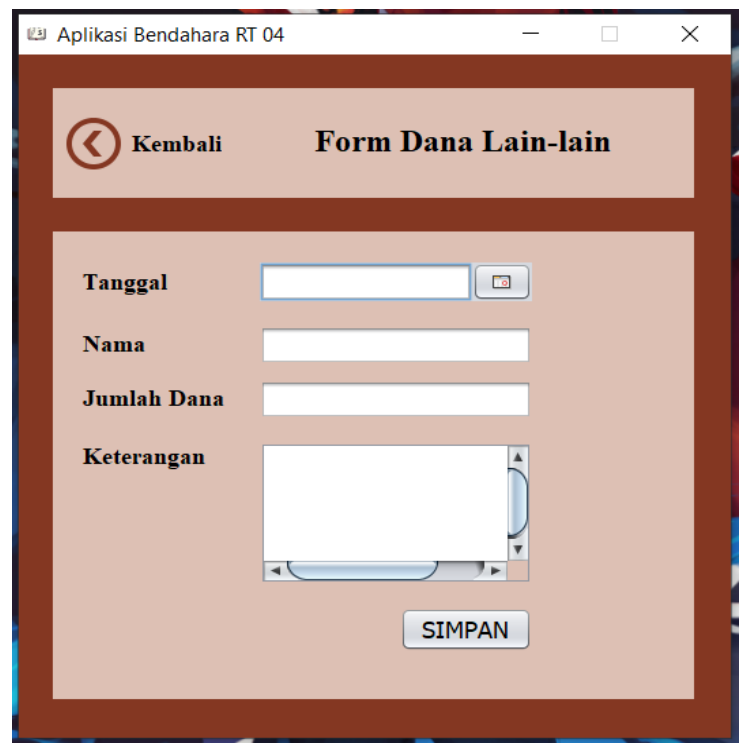

Sumber : Dokumen Pribadi

Gambar 8. Tampilan Form Dana Lain-lain

Tampilan form dana lain-lain ini berisikan tanggal, nama, jumlah dana, dan keterangan.

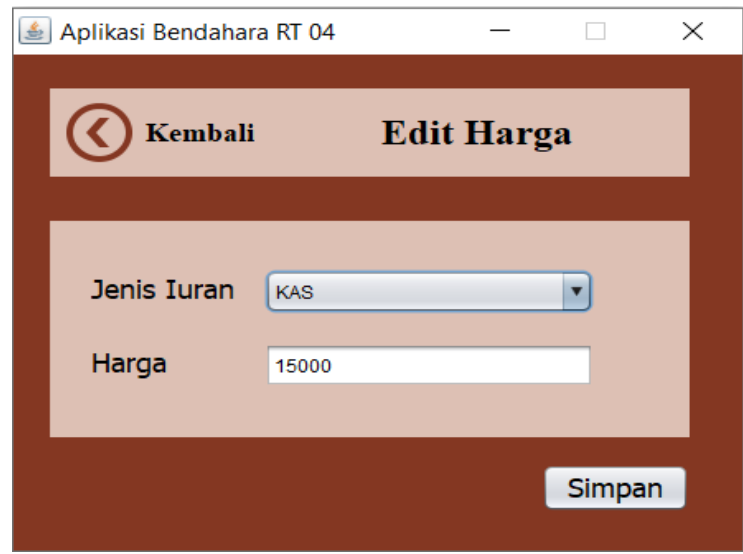

Sumber : Dokumen Pribadi

Gambar 9. Tampilan Edit Harga

Tampilan form edit harga ini berisikan jenis iuran, dan harga.

JURNAL ILMIAH KOMPUTER GRAFIS Vol. 14, No. 2, Des 2021: $271-286$ 


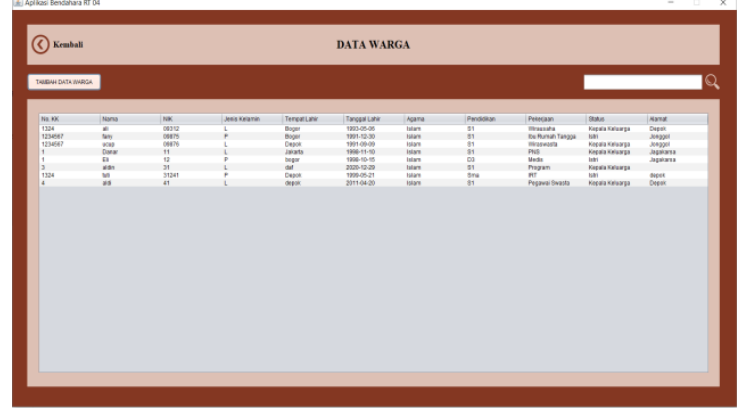

Sumber : Dokumen Pribadi

Gambar 10. Tampilan Tabel Data Warga

Tampilan ini berisi data-data warga.

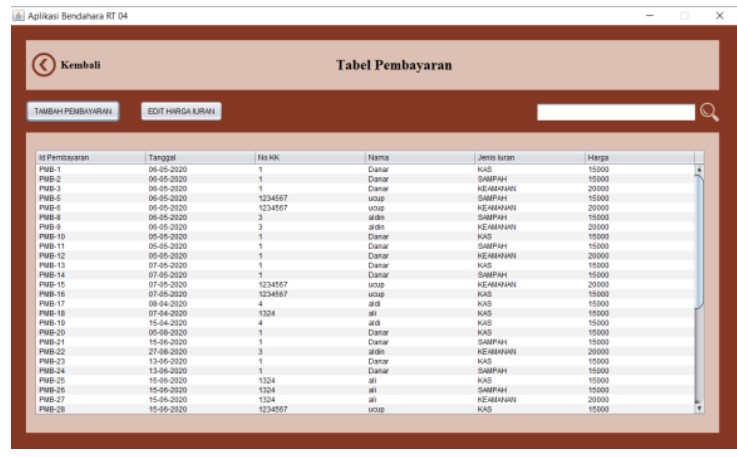

Sumber : Dokumen Pribadi

Gambar 11. Tampilan Tabel Pembayaran

Tampilan ini berisi data-data pembayaran iuran.

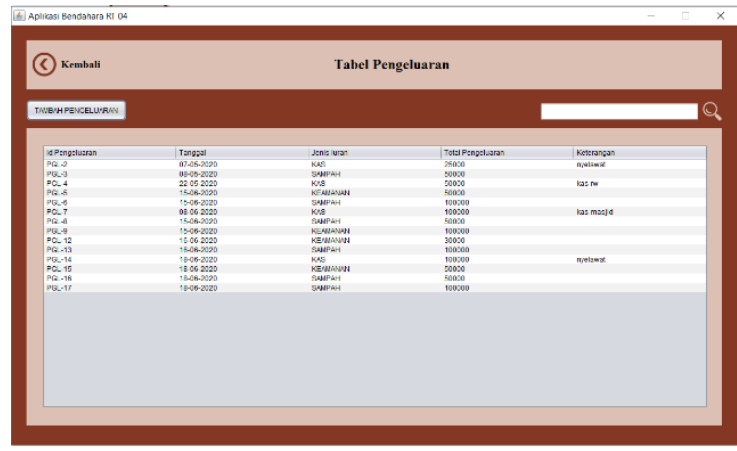

Sumber : Dokumen Pribadi

Gambar 12. Tampilan Tabel Pengeluaran Iuran

JURNAL ILMIAH KOMPUTER GRAFIS Vol. 14, No. 2, Des 2021 : $271-286$ 
Tampilan ini berisi data-data pengeluaran iuran.

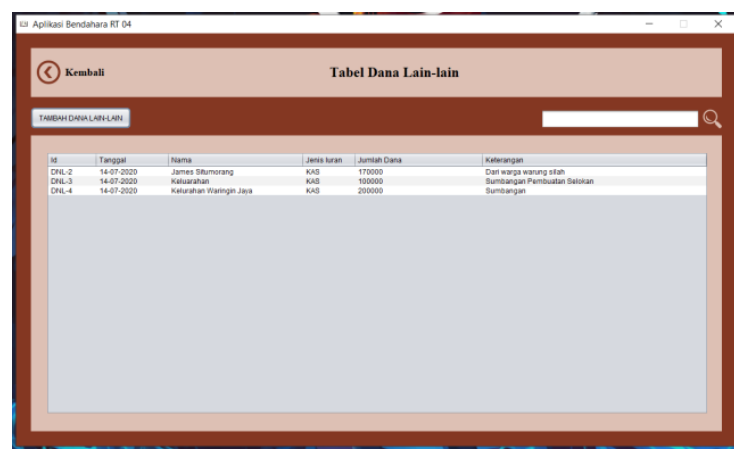

Sumber : Dokumen Pribadi

Gambar 13. Tampilan Tabel Dana Lain-lain

Tampilan ini berisi data-data dana lain-lain.

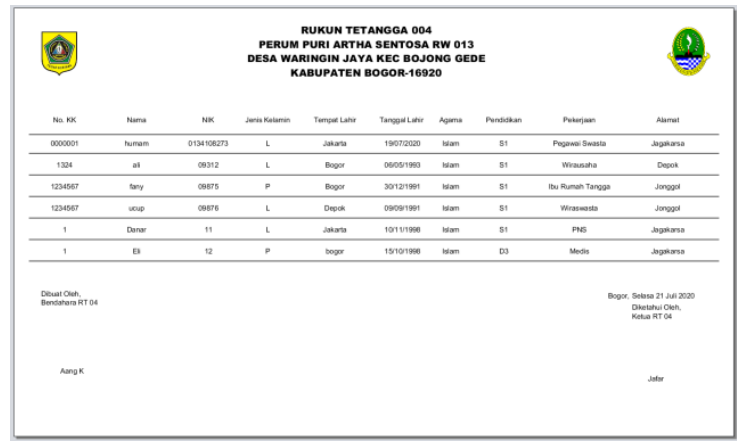

Sumber : Dokumen Pribadi

Gambar 14. Tampilan Laporan Data Warga

Tampilan laporan data warga merupakan hasil dari inputan data warga, kemudian dicetak lalu menghasilkan keluaran berupa laporan data seluruh warga. 


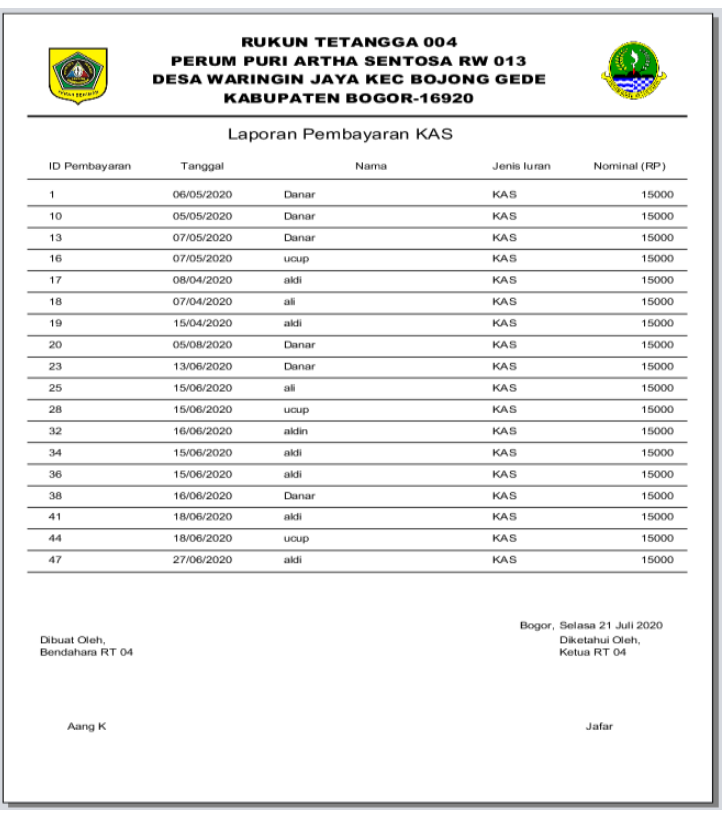

Sumber : Dokumen Pribadi

Gambar 15. Tampilan Laporan Pembayaran Kas

Tampilan laporan data pembayaran kas merupakan hasil dari inputan data pembayaran kas, kemudian dicetak lalu menghasilkan keluaran berupa laporan data seluruh pembayaran kas.

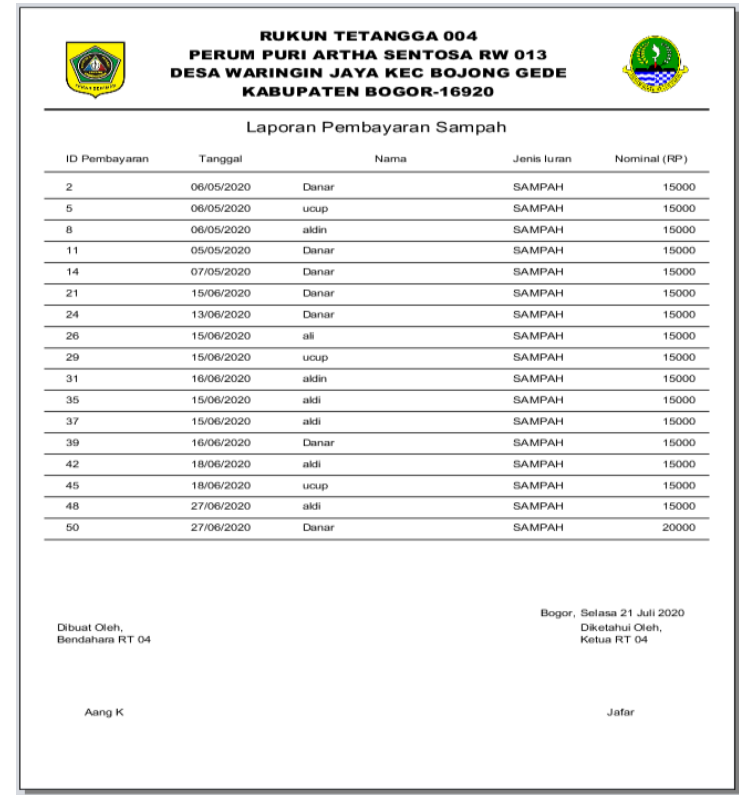

Sumber : Dokumen Pribadi

JURNAL ILMIAH KOMPUTER GRAFIS Vol. 14, No. 2, Des 2021: $271-286$ 
Gambar 16. Tampilan Laporan Pembayaran Sampah

Tampilan laporan data pembayaran sampah merupakan hasil dari inputan data pembayaran sampah, kemudian dicetak lalu menghasilkan keluaran berupa laporan data seluruh pembayaran sampah.

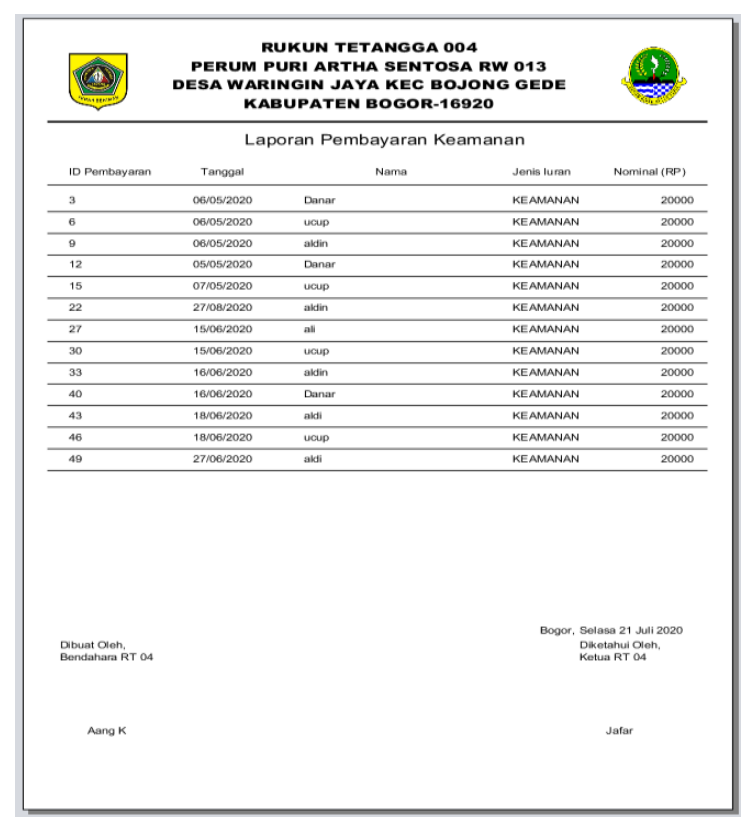

Sumber : Dokumen Pribadi

Gambar 17. Tampilan Laporan Pembayaran Keamanan

Tampilan laporan data pembayaran keamanan merupakan hasil dari inputan data pembayaran keamanan, kemudian dicetak lalu menghasilkan keluaran berupa laporan data seluruh pembayaran keamanan. 


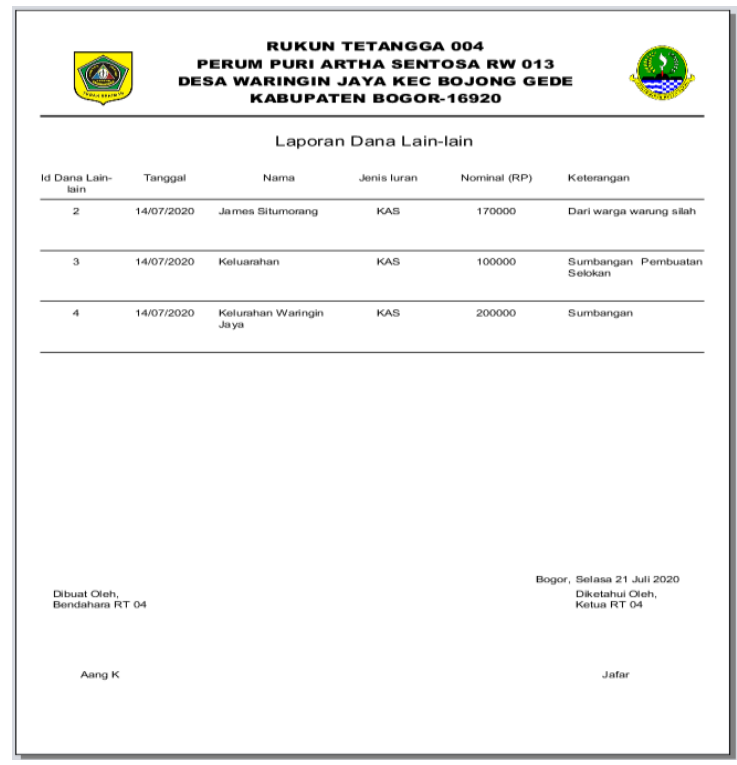

Sumber : Dokumen Pribadi

Gambar 18. Tampilan Laporan Dana lain-lain

Tampilan laporan data dana lain-lain merupakan hasil dari inputan data dana lain-lain, kemudian dicetak lalu menghasilkan keluaran berupa laporan data seluruh dana lain-lain.

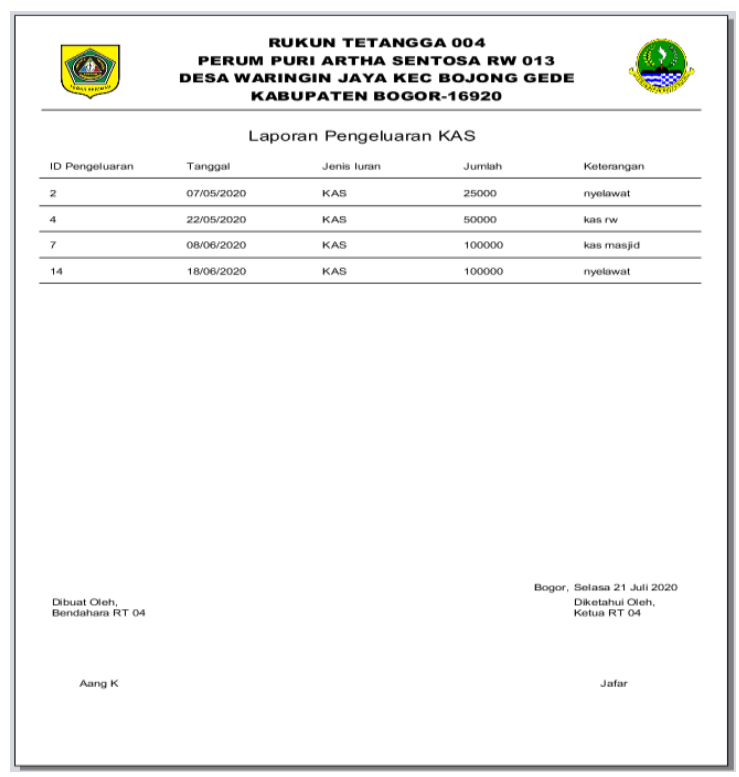

Sumber : Dokumen Pribadi

Gambar 19. Tampilan Laporan Pengeluaran Kas

JURNAL ILMIAH KOMPUTER GRAFIS Vol. 14, No. 2, Des 2021: $271-286$ 
Tampilan laporan data pengeluaran kas merupakan hasil dari inputan data pengeluaran kas, kemudian dicetak lalu menghasilkan keluaran berupa laporan data seluruh pengeluaran kas.

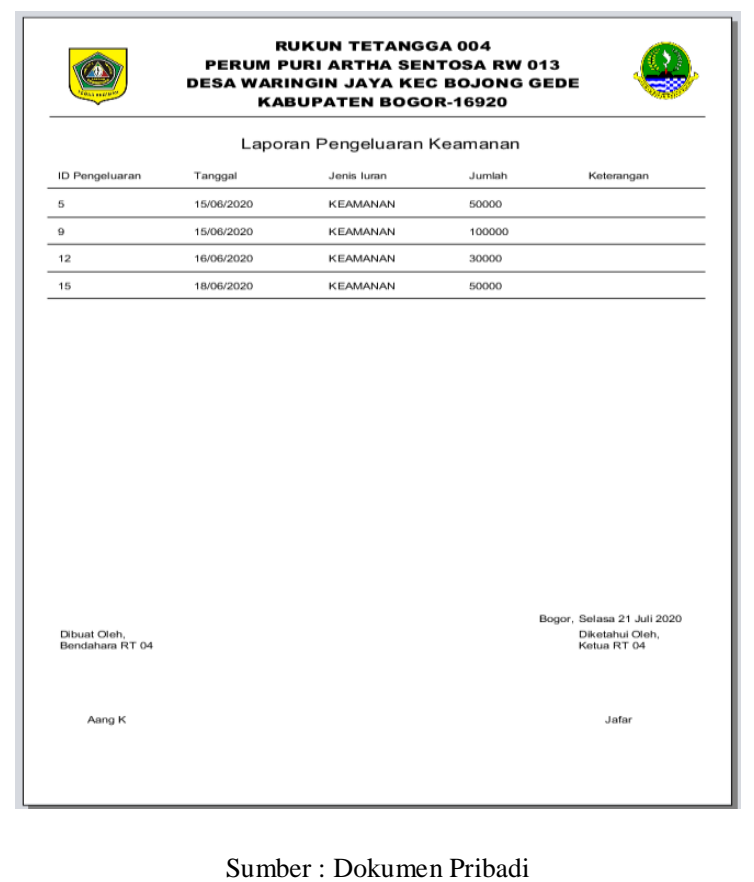

Gambar 20. Tampilan Laporan Pengeluaran Keamanan

Tampilan laporan data pengeluaran keamanan merupakan hasil dari inputan data pengeluaran keamanan, kemudian dicetak lalu menghasilkan keluaran berupa laporan data seluruh pengeluaran keamanan. 


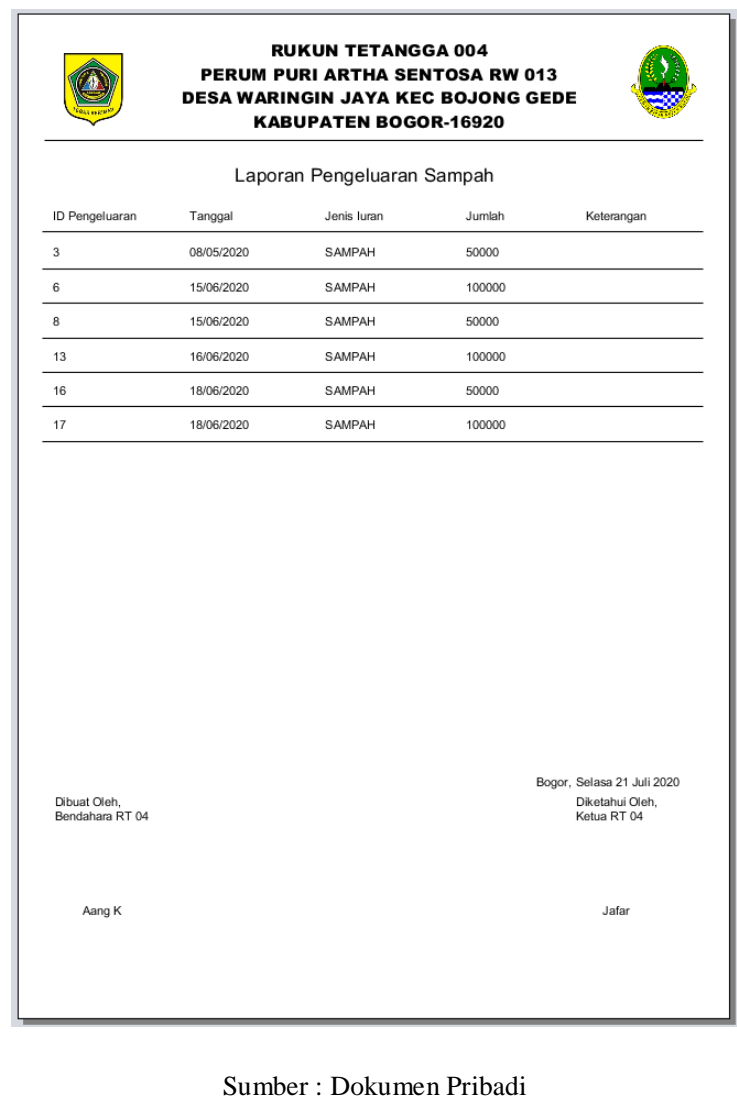

Gambar 21. Tampilan Laporan Pengeluaran Sampah

Tampilan laporan data pengeluaran sampah merupakan hasil dari inputan data pengeluaran sampah, kemudian dicetak lalu menghasilkan keluaran berupa laporan data seluruh pengeluaran sampah.

\section{Simpulan}

Berdasarkan analisa yang dilakukan, maka rancangan sistem administrasi keuangan pada tingkat RT 04 RW 13 desa Waringin Jaya dapat diterapkan dan menjadi salah satu solusi yang tepat bagi RT ini. Sehingga dapat diambil simpulan bahwa hasil sistem komputerisasi dapat membantu RT ini dalam mempercepat proses-proses pengolahan data sehingga kekurangan pada sistem yang lama dapat teratasi. Program memudahkan mengolah data khususnya di Bagian pendataan iuran dan peningkatan efisiensi.

\section{DAFTAR PUSTAKA}

[1] W. Hidayat, F. Maatuf and S. Bahari, "Perancangan Media Video Desain Interior Sebagai Salah Satu Penunjang Promosi Dan Informasi Di PT. Wans Desain Group," Journal Cerita, vol. 2, no. 1,

JURNAL ILMIAH KOMPUTER GRAFIS Vol. 14, No. 2, Des 2021: $271-286$ 
pp. 35-49, 2016.

[2] P. Kristanto, Ekologi Industri, Yogyakarta: Andi offset, 2013.

[3] S. Chan, Membuat Aplikasi Database dengan PowerBuilder 12.6 dan MySQL, Jakarta: Elex Media Komputindo, 2017.

[4] W. R. Murhadi, Analisis Laporan Keuangan: Proyeksi dan Valuasi Saham, Jakarta: Salemba Empat, 2013.

[5] R. A. Sukamto and M. Shalahuddin, Analisa dan Desain Sistem Informasi, Yogyakarta: Andi Offset, 2013.

[6] R. A. Sukamto and M. Shalahuddin, Rekayasa perangkat lunak terstruktur dan berorientasi objek, Bandung: Informatika, 2013. 